\title{
FORTIFIKASI KUE KEIK MENGGUNAKAN BUBUK Gracilaria spp. DAN Sargassum filipendula SEBAGAI SUMBER ASAM LEMAK OMEGA-3 DAN IODIUM
}

\author{
M. Darmawan, Tazwir dan Hari Eko Irianto")
}

\begin{abstract}
ABSTRAK
Riset fortifikasi bubuk Gracilaria spp. dan Sargassum filipendula sebagai sumber asam lemak omega-3 dan iodium ke dalam kue keik (cake) telah dilakukan. Penelitian dilakukan untuk melihat pengaruh jenis rumput laut (Sargassum filipendula dan Gracilaria spp.) serta jumlah penambahan bubuk rumput laut $(0,1,2,3,4$ dan $5 \%$ ) terhadap mutu organoleptik (rupa, warna, bau, rasa dan tekstur), kadar asam lemak omega-3, iodium, dan komposisi proksimatnya. Hasil penelitian menunjukkan bahwa jenis rumput laut tidak memberikan pengaruh yang nyata terhadap kadar abu, protein, lemak, karbohidrat dan iodium kue keik, tetapi berpengaruh nyata terhadap kadar air dan asam lemak omega-3 kue keik, sedangkan jumlah bubuk rumput laut yang ditambahkan berpengaruh nyata terhadap kadar air, abu, protein, lemak, karbohidrat, iodium dan asam lemak omega-3 pada kue keik. Kadar asam lemak omega-3 tertinggi diperoleh dari penambahan Gracilaria spp. sebanyak $2 \%$ yaitu $0,499 \mathrm{mg} / 100 \mathrm{~g}$ kue keik. Kadar iodium tertinggi diperoleh dari penambahan Gracilaria spp. sebanyak $5 \%$ yaitu sebesar $0,191 \mathrm{mg} / 100 \mathrm{~g}$ kue keik. Hasil uji organoleptik menunjukkan bahwa kue keik yang disukai oleh panelis berdasarkan warna, bau, rasa dan tekstur dibuat dari formula yang mengandung bubuk Sargassum filipendula 1\% atau bubuk Gracilaria spp. $2 \%$.
\end{abstract}

ABSTRACT: Fortification of cake using Gracillaria spp. and Sargassum filipendula as a source of omega-3 fatty acid and iodium. By: M. Darmawan, Tazwir and Hari Eko Irianto

An experiment had been conducted on cake fortification using Gracillaria spp. and Sargassum filipendula powder as a source of omega-3 fatty acid and iodium. The experiment was aimed to observe the effects of seaweeds powder (Sargassum filipendula and Gracilaria spp.) addition at various concentration $(0,1,2,3,4$ and 5\%) on organoleptic acceptability (appearance, color, odor, taste and texture), omega-3 fatty acid content, iodium content and proximate composition of cake produced. Results indicated that kinds of seaweed showed insignificant effect on ash, protein, fat, carbohydrate and iodium contents but gave significant effect on moisture and omega-3 fatty acids contents of cake. On the other hand, the seaweed powder concentration treatment gave significant effect on moisture, ash, fat, carbohydrate, iodium and omega three-3 fatty acid contents of cake. Addition of $2 \%$ Gracilaria spp. gave the highest value of omega-3 fatty acid content $(0.499 \mathrm{~g} / 100 \mathrm{~g}$ cake) and addition of 5\% Gracilaria spp. gave the highest value of iodium content (0.191 $\mathrm{mg} / 100 \mathrm{~g}$ cake). The organoleptic test showed that the most acceptable formula was the one with addition of $1 \%$ Sargassum filipendula or $2 \%$ Gracilaria spp. powder.

KEYWORDS: Sargassum filipendula, Gracilaria spp., cake, fortification, omega-3 fatty acid, iodium.

\section{PENDAHULUAN}

Rumput laut merupakan salah satu komoditas hasil perikanan yang sedang ditingkatkan pemanfaatannya. Hal ini dikarenakan banyak sekali manfaat yang dapat dihasilkan dengan cara mengoptimalkan seluruh potensi rumput laut yang ada. Pada mulanya orang menggunakan rumput laut hanya untuk bahan sayur saja. Namun seiring berjalannya waktu maka pengetahuan tentang rumput laut dan teknik pemanfaatannya semakin berkembang pula.

Beberapa jenis rumput laut yang bermanfaat bagi manusia adalah dari jenis rumput laut merah dan coklat. Di dalam rumput laut merah terkandung berbagai senyawa di antaranya adalah agar-agar, karaginan, porpiran, maupun furcelaran. Di samping itu di dalam rumput laut merah juga terkandung pigmen fikobilin yang terdiri dari fikoeritrin dan fikosianin yang berfungsi sebagai cadangan makanan berupa

Peneliti pada Pusat Riset Pengolahan Produk dan Sosial Ekonomi Kelautan dan Perikanan 


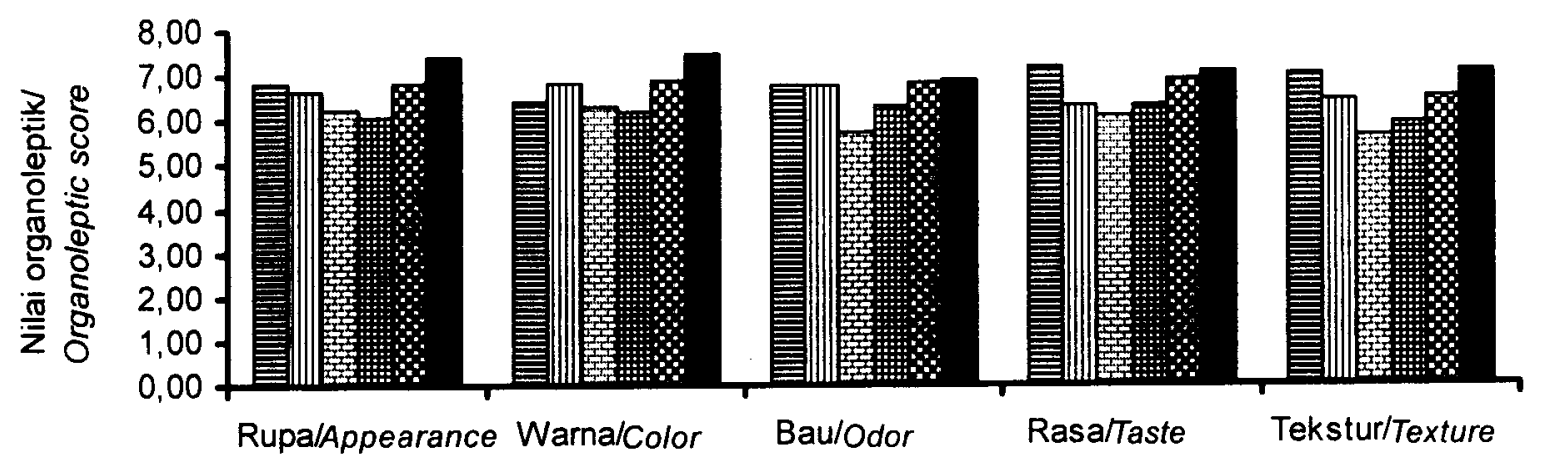

Parameter pengujian/Experimental parameter

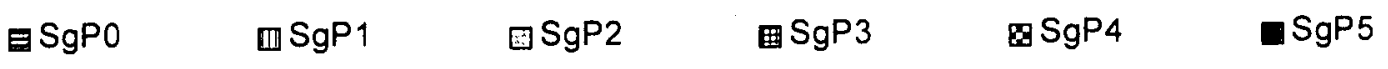

\footnotetext{
Keterangan/Note : $\mathrm{Sg}=$ Sargassum filipendula; $\mathrm{P} 0=$ konsentrasi $/$ concentration $0 \%$

$\mathrm{P} 1=$ konsentrasi/concentration $1 \% ; \mathrm{P} 2$ = konsentrasi/concentration $2 \%$;

$\mathrm{P} 3=$ konsentrasi/concentration $3 \%$;

$\mathrm{P} 4=$ konsentrasi/concentration $4 \% ; \mathrm{P} 5=$ konsentrasi/concentration $5 \%$
}

Gambar 1. Nilai organoleptik kue keik yang difortifikasi dengan bubuk Sargassum filipendula.

Figure 1. Organoleptic score of cake fortified with Sargassum filipendula powder.

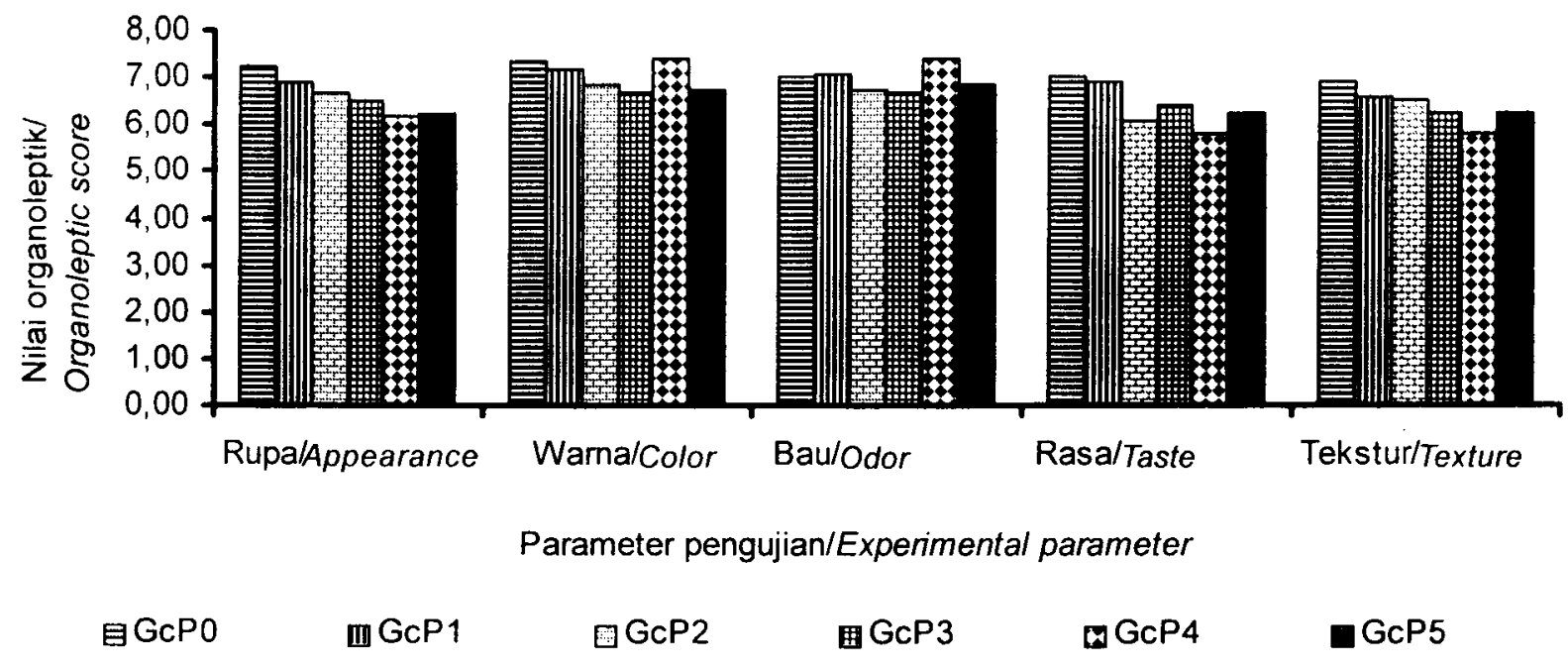

\footnotetext{
Keterangan/Note: $\quad \mathrm{Gc}=$ Gracilaria spp $; \mathrm{P0}=$ konsentrasi/concentration $0 \%$

$\mathrm{P} 1=$ konsentrasi/concentration $1 \% ; \mathrm{P} 2=$ konsentrasi/concentration $2 \%$;

$\mathrm{P} 3=$ konsentrasi/concentration $3 \%$;

P4 $=$ konsentrasi/concentration 4\%; P5 = konsentrasi/concentration $5 \%$.
}

Gambar 2. Nilai organoleptik kue keik yang difortifikasi dengan bubuk Gracilaria spp.

Figure 2. Organoleptic score of cake fortified with Gracilaria spp. powder. 
jenis Sargassum filipendula maupun Gracilaria spp. memberikan peningkatan kepada kadar asam lemak omega-3. Konsentrasi bubuk rumput laut juga berpengaruh kepada kadar asam lemak omega-3 karena semakin tinggi jumlah penambahannya maka semakin tinggi pula kadar asam lemak omega-3 pada produk. Namun jumlah ini masih jauh bila dibandingkan dengan kadar asam lemak omega-3 yang dimiliki oleh bahan baku kedua jenis rumput laut. Hal ini dikarenakan konsentrasi penambahan bubuk rumput laut ke dalam formulasi kue keik masin sangat kecil.

Hasil uji lanjut Beda Nyata Jujur menunjukkan bahwa perlakuan jenis rumput laut memberikan pengaruh yang nyata terhadap kadar asam lemak omega-3 kue keik. Pada perlakuan konsentrasi penambahan bubuk rumput laut diketahui bahwa untuk rumput laut jenis Gracilaria spp., konsentrasi penambahan sebanyak 0 dan $1 \%$ tidak memberikan pengaruh yang nyata kepada kadar asam lemak omega-3 kue keik, tetapi konsentrasi penambahan sebanyak $2,3,4$ dan $5 \%$ memberikan pengaruh yang nyata terhadap kadar asam lemak omega-3. Sedangkan untuk rumput laut jenis Sargassum filipendula konsentrasi penambahan sebanyak 0 dan $5 \%$ tidak memberikan pengaruh yang nyata kepada kadar asam lemak omega-3 kue keik, tetapi konsentrasi penambahan sebanyak $1,2,3$ dan $4 \%$ memberikan pengaruh yang nyata terhadap kadar asam lemak omega-3. Hasil analisis kadar asam lemak omega-3 kue keik dapat dilihat pada Gambar 3.

\section{Kadar lodium}

Nilai rata-rata kadar iodium produk kue keik yang dihasilkan berkisar antara $0,13-0,19 \mathrm{mg} / 100 \mathrm{~g}$ kue keik. Kadar iodium tertinggi diperoleh dari perlakuan penambahan bubuk rumput laut jenis Gracilaria spp. dengan konsentrasi $5 \%$. Sedangkan nilai kadar iodium terendah diperoleh dari perlakuan tanpa penambahan bubuk rumput laut (kontrol). Semakin tinggi konsentrasi penambahan bubuk rumput laut maka semakin besar pula peningkatan kadar iodium kue keik yang dihasilkan. Hal ini disebabkan karena rumput laut baik jenis Sargassum filipendula maupun Gracilaria spp. memiliki kandungan yang tinggi akan iodium. Rumput laut merah maupun coklat merupakan bahan makanan yang baik sebagai sumber iodium (Indriani \& Sumiarsih, 1997). Rumput laut merah memiliki kisaran kadar iodium antara $0,10-0,15 \%$, sedangkan rumput laut coklat memiliki kadar iodium berkisar antara 0,10-0,80\% (Winarno, 1990).

Hasil analisis ragam dengan selang kepercayaan $95 \%$ menunjukkan bahwa perlakuan jenis rumput laut dan interaksi antar perlakuan tidak memberikan pengaruh yang nyata terhadap kadar iodium kue keik, sedangkan perlakuan konsentrasi penambahan bubuk rumput laut $(0,1,2,3,4$ dan $5 \%)$ memberikan pengaruh yang nyata terhadap kadar iodium kue keik. Peningkatan konsentrasi bubuk rumput laut membuat peningkatan yang cukup signifikan pada kadar iodium kue keik.

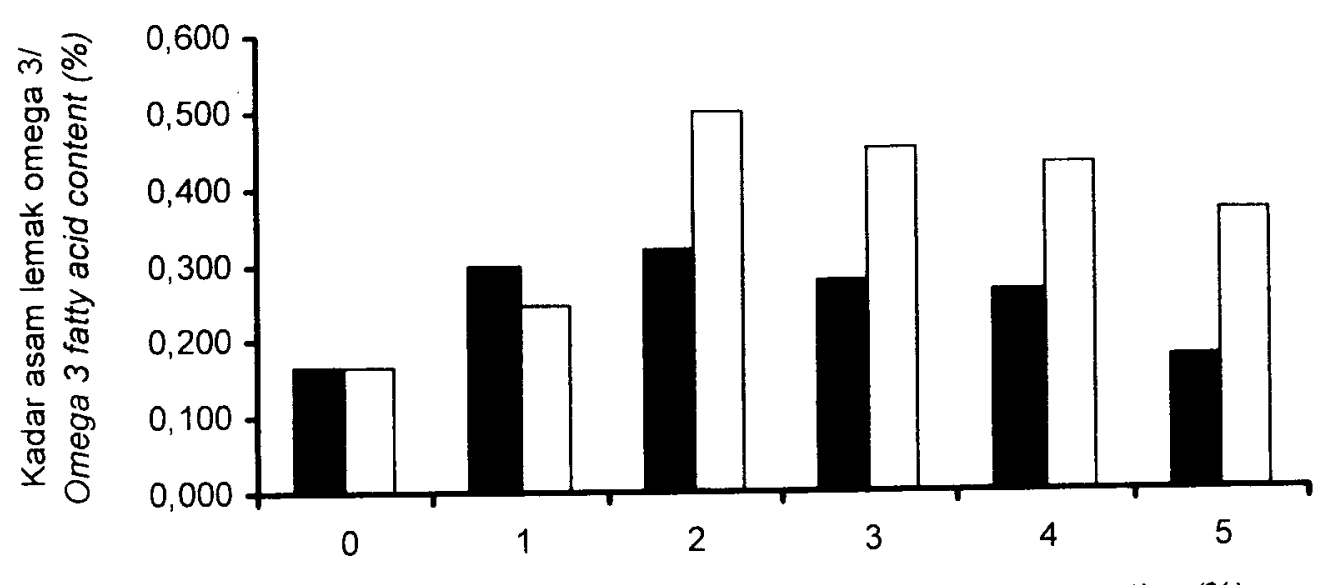

Konsentrasi bubuk rumput laut/Seaweed powder concentration (\%)

- Sargassum filipendula $\quad$ Gracilania spp.

Gambar 3. Kadar asam lemak omega-3 kue keik yang difortifikasi dengan bubuk rumput laut.

Figure 3. Omega-3 fatty acids of cake fortified with seaweed powder. 
Hasil uji lanjut Beda Nyata Jujur terhadap perlakuan konsentrasi penambahan bubuk rumput laut diketahui bahwa konsentrasi penambahan bubuk rumput laut sebesar $0,1,2,3$ dan $4 \%$ tidak memberikan pengaruh yang nyata terhadap kadar iodium produk. Namun konsentrasi penambahan sebanyak $5 \%$ berpengaruh nyata terhadap kadar iodium produk. Hal ini dapat dilihat dari jumlah kadar iodium tertinggi produk kue keik didapatkan pada perlakuan penambahan bubuk rumput laut sebanyak $5 \%$ untuk kedua jenis rumput laut tersebut. Dengan hasil ini dapat dikatakan bahwa penambahan $5 \%$ bubuk rumput laut dari kedua jenis rumput laut secara nyata meningkatkan kadar iodium produk namun konsentrasi yang tinggi tersebut kurang disukai oleh panelis karena adanya warna yang kecoklatan (gelap) dan bau rumput laut yang menonjol. Dengan demikian pada penelitian ini terlihat bahwa bubuk rumput laut tidak dapat digunakan sebagai sumber iodium dalam fortifikasi kue keik. Hasil analisis kadar iodium kue keik dapat dilihat pada Gambar 4. abu $18 \%$, protein $3,3 \%$, abu tak larut dalam asam $0,2 \%$ dan asam lemak omega-3 $9,1 \mathrm{mg} / 100 \mathrm{~g}$. Komposisi proksimat produk kue keik dapat dilihat pada Tabel 1.

\section{Kadar Air}

Kadar air kue keik yang ditambah dengan bubuk rumput laut pada berbagai konsentrasi berkisar antara $19,2-38,1 \%$. Nilai tertinggi diperoleh dari perlakuan tanpa penambahan bubuk rumput laut (kontrol), sedangkan nilai terendah diperoleh dari perlakuan penambahan bubuk rumput laut jenis Gracilaria spp. sebanyak $5 \%$. Secara umum nilai kadar air yang dimiliki oleh kue keik berfluktuasi yakni dengan bertambahnya jumlah bubuk rumput laut yang diberikan maka kadar air kue keik akan mengalami penurunan.

Hasil analisis ragam dengan selang kepercayaan $95 \%$ menunjukkan bahwa perlakuan jenis rumput laut (Sargassum filipendula dan Gracilaria spp.)

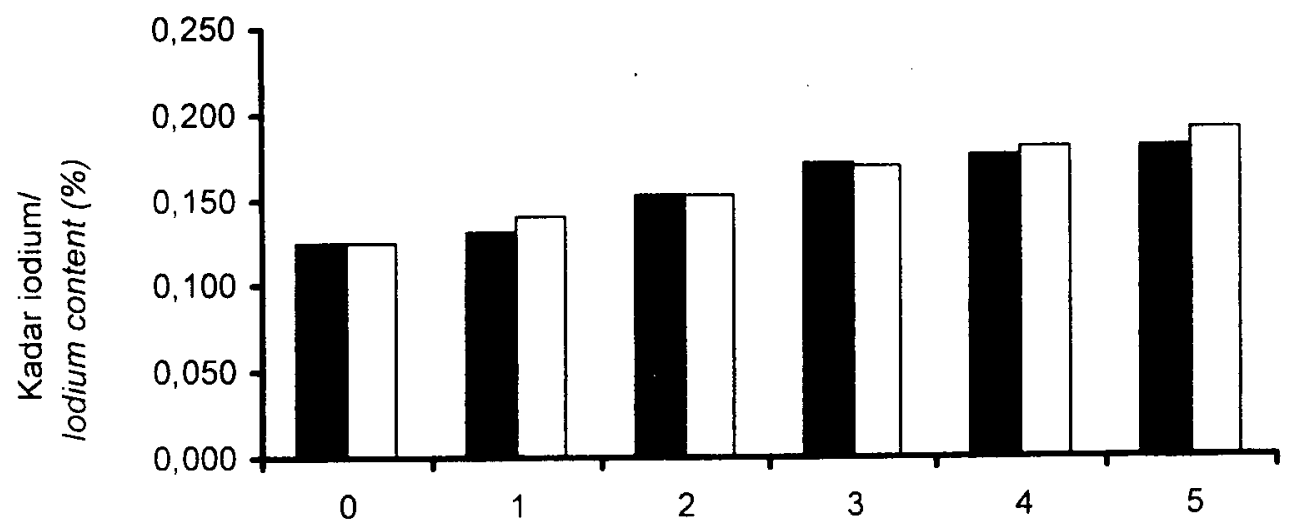

Konsentrasi bubuk rumput laut/Seaweed powder concentration (\%)

Sargassum filipendula

Gracilaria spp

Gambar 4. Kadar iodium kue keik yang difortifikasi dengan bubuk rumput laut.

Figure 4. lodium content of cake fortified with seaweeds powder.

\section{Komposisi Proksimat Bahan Baku dan Produk}

Bahan baku yang merupakan bubuk dari rumput laut Sargassum filipendula dan Gracilaria spp. yang digunakan pada riset ini mempunyai mutu kimiawi sebagai berikut. Bubuk Sargassum filipendula, mempunyai kadar air $14,1 \%$, kadar abu $18 \%$, protein $5 \%$. abu tak larut dalam asam $0,5 \%$ dan asam lemak omega-3 $13,8 \mathrm{mg} / 100 \mathrm{~g}$, sedangkan rumput laut Gracilaria spp. mempunyai kadar air $13,1 \%$, kadar memberikan pengaruh yang nyata terhadap kadar air produk kue keik yang dihasilkan. Konsentrasi penambahan bubuk rumput laut $(0,1,2,3,4$ dan $5 \%)$ dan interaksi antar perlakuan juga memberikan pengaruh yang nyata pada kadar air produk kue keik.

Hasil uji lanjut Beda Nyata Jujur menunjukkan bahwa perlakuan jenis rumput laut berbeda nyata untuk tiap perlakuan, sedangkan perlakuan konsentrasi penambahan juga menunjukkan perbedaan yang nyata untuk tiap konsentrasi penambahan terhadap 
Tabel 1. Komposisi proksimat kue keik dengan penambahan bubuk rumput laut Table 1. Proximate composition of cake fortified with seaweeds powder

\begin{tabular}{lcccccc}
\hline $\begin{array}{c}\text { Rumput laut } \\
\text { Seaweeds }\end{array}$ & $\begin{array}{c}\text { Penambahan/ } \\
\text { Addition level } \\
(\%)\end{array}$ & $\begin{array}{c}\text { Air/ } \\
\text { Moisture } \\
(\%)\end{array}$ & $\begin{array}{c}\text { Abul } \\
\text { Ash } \\
(\%)\end{array}$ & $\begin{array}{c}\text { Protein } \\
(\%)\end{array}$ & $\begin{array}{c}\text { Lemakd } \\
\text { Fat } \\
(\%)\end{array}$ & $\begin{array}{c}\text { Karbohidrat } \\
\text { Carbohydrate } \\
(\%)\end{array}$ \\
\hline $\begin{array}{c}\text { Sargassum } \\
\text { filipendula }\end{array}$ & 0 & $38.11 \pm 0.30$ & $0.83 \pm 0.03$ & $14.76 \pm 1.78$ & $12.74 \pm 1.33$ & $33.56 \pm 0.37$ \\
& 1 & $28.30 \pm 0.21$ & $1.03 \pm 0.03$ & $13.33 \pm 1.88$ & $20.13 \pm 1.60$ & $37.21 \pm 1.54$ \\
& 2 & $25.95 \pm 0.28$ & $0.98 \pm 0.07$ & $13.21 \pm 1.00$ & $18.77 \pm 1.16$ & $41.09 \pm 1.54$ \\
& 3 & $25.93 \pm 0.25$ & $1.14 \pm 0.08$ & $12.65 \pm 1.20$ & $18.22 \pm 1.54$ & $42.06 \pm 1.50$ \\
& 4 & $25.91 \pm 0.16$ & $1.25 \pm 0.07$ & $12.35 \pm 1.77$ & $16.09 \pm 1.02$ & $44.40 \pm 1.64$ \\
& 5 & $28.80 \pm 0.07$ & $1.31 \pm 0.08$ & $12.04 \pm 1.47$ & $12.81 \pm 1.15$ & $45.04 \pm 1.36$ \\
\hline Gracilaria spp. & 0 & $38.11 \pm 0.30$ & $0.83 \pm 0.03$ & $14.76 \pm 1.78$ & $12.74 \pm 1.33$ & $33.56 \pm 0.37$ \\
& 1 & $27.08 \pm 0.11$ & $1.00 \pm 0.01$ & $14.50 \pm 1.13$ & $18.79 \pm 1.12$ & $39.23 \pm 0.33$ \\
& 2 & $25.18 \pm 0.03$ & $0.98 \pm 0.01$ & $14.12 \pm 1.58$ & $20.61 \pm 1.57$ & $39.11 \pm 1.27$ \\
& 3 & $25.68 \pm 0.11$ & $1.09 \pm 0.04$ & $11.96 \pm 1.64$ & $18.97 \pm 1.97$ & $42.30 \pm 0.99$ \\
& 4 & $27.37 \pm 0.66$ & $1.23 \pm 0.14$ & $11.34 \pm 1.19$ & $17.51 \pm 1.00$ & $42.65 \pm 1.06$ \\
& 5 & $19.23 \pm 0.47$ & $1.19 \pm 0.03$ & $11.20 \pm 1.20$ & $16.05 \pm 1.06$ & $52.33 \pm 3.78$ \\
\hline
\end{tabular}

kadar air kue keik yang dihasilkan. Interaksi antara perlakuan jenis rumput laut dan konsentrasi penambahan bubuk rumput laut juga memberikan pengaruh yang nyata terhadap kadar air produk. Penambahan bubuk rumpur laut dengan konsentrasi tertentu mengakibatkan pengurangan penggunaan tepung terigu dalam adonan sehingga akan mengurangi daya mengikat air pada produk.

\section{Kadar Abu}

Kadar abu yang diperoleh berkisar antara 0,8 $1,3 \%$. Nilai rata-rata tertinggi diperoleh dari perlakuan penambahan bubuk rumput laut jenis Sargassum filipendula dengan konsentrasi $5 \%$, sedangkan nilai rata-rata terendah dimiliki oleh perlakuan tanpa penambahan rumput laut (kontrol). Dari hasil analisis ragam dengan selang kepercayan $95 \%$ ditunjukkan bahwa perlakuan jenis rumput laut dan interaksi antar kedua perlakuan tidak memberikan pengaruh yang nyata terhadap kadar abu produk, sedangkan konsentrasi penambahan bubuk rumput laut memberikan pengaruh yang nyata terhadap kadar abu produk kue keik.

Dari hasil uji lanjut Beda Nyata Jujur terhadap perlakuan konsentrasi penambahan bubuk rumput laut diketahui bahwa perlakuan penambahan bubuk rumput laut sebanyak $0,1,2$ dan $3 \%$ tidak memberikan pengaruh yang nyata terhadap kadar abu produk. sedangkan penambahan bubuk rumput laut sebesar 4 dan $5 \%$ memberikan pengaruh yang nyata terhadap kadar abu produk.

Bila dibandingkan dengan kontrol, kadar abu yang dimiliki oleh produk kue keik semakin meningkat seiring dengan peningkatan konsentrasi penambahan bubuk rumput laut. Hal ini diduga karena rumput laut memiliki kadar abu yang tinggi sehingga akan méningkatkan kadar abu dari produk yang dihasilkan. Menurut Yunizal et al. (2002), kadar abu untuk rumput laut jenis Gracilaria spp. adalah $14,8 \%$ (bobot kering) dan jenis Sargassum filipendula adalah 32,9\% (bobot kering). Kadar abu bahan baku rumput laut jenis Sargassum filipendula maupun Gracilaria spp. yang telah dianalisis untuk digunakan pada penelitian ini adalah berkisar antara $17,9-18,5 \%$. Nilai ini cukup tinggi sehingga dapat mempengaruhi kadar abu produk kue keik yang dihasilkan. Penggunaan bubuk rumput laut yang difortifikasikan ke dalam formulasi kue keik pada penelitian ini cenderung meningkatkan kadar abu produk yang dihasilkan.

\section{Kadar Protein}

Kadar protein produk kue keik yang masing-masing mendapatkan perlakuan penambahan bubuk rumput laut dari jenis Sargassum filipendula dan Gracilaria spp. dengan konsentrasi $0,1,2,3,4$ dan $5 \%$ adalah berkisar antara $11,2-14,7 \%$. Nilai kadar potein 
tertinggi diperoleh dari perlakuan jenis rumput laut Gracilaria spp. dengan konsentrasi $1 \%$, sedangkan nilai kadar protein yang paling rendah dimiliki oleh perlakuan penambahan rumput laut Gracilaria spp. dengan konsentrasi $5 \%$.

Hasil analisis ragam dengan selang kepercayaan $95 \%$ menunjukkan bahwa perlakuan jenis rumput laut baik Sargassum filipendula maupun Gracilaria spp. tidak menunjukkan perbedaan yang nyata terhadap kadar protein produk, sedangkan perlakuan konsentrasi penambahan bubuk rumput laut dan interaksi antar perlakuan memberikan pengaruh yang nyata terhadap kadar protein produk. Dari uji lanjut Beda Nyata Jujur terhadap perlakuān konsentrasi penambahan bubuk rumput laut diketahui bahwa penambahan bubuk rumput laut sebesar 0,2 dan $4 \%$ memberikan pengaruh yang nyata terhadap kadar protein kue keik.

Perbedaan nilai kadar protein yang dimiliki diduga dipengaruhi oleh kadar protein bahan baku awal yaitu rumput laut yang digunakan dan konsentrasi yang diberikan. Nilai kadar protein kue keik yang didapatkan bervariasi. Akan tetapi bila dibandingkan dengan produk kontrol terlihat adanya penurunan kadar protein produk yang dihasilkan. Hal ini diduga karena terjadinya pengurangan jumlah tepung terigu yang diberikan seiring dengan makin tingginya jumlah bubuk rumput laut yang ditambahkan. Kadar protein tepung terigu lebih tinggi bila dibandingkan dengan kadar protein bubuk Sargassum filipendula maupun bubuk rumput laut Gracilaria spp. Kadar protein tepung terigu adalah 8,9\% (Direktorat Gizi, 1995), sedangkan kadar protein bubuk rumput laut Gracilaria spp. hanya $4,7 \%$ (Badan Penelitian dan Pengembangan Pertanian, 1985) dan untuk kadar protein rumput laut jenis Sargassum filipendula adalah $4,5 \%$ (Yunizal et. al., 2002). Hal ini mengakibatkan kadar protein produk kue keik yang dihasilkan akan berkurang bila pada bahan baku ditambahkan bubuk rumput laut.

\section{Kadar Lemak}

Kadar lemak produk kue keik adalah berkisar antara $12,7-20,6 \%$. Nilai rata-rata tertinggi untuk kadar lemak adalah pada perlakuan penambahan bubuk rumput laut jenis Gracilaria spp. dengan konsentrasi $2 \%$, sedangkan nilai rata-rata terendah dimiliki oleh kue keik dengan perlakuan tanpa penambahan bubuk rumput laut (kontrol). Kadar lemak produk kue keik yang dihasilkan bervariasi, tetapi bila dibandingkan dengan produk kontrol terjadi peningkatan kadar lemak produk kue keik

Hasil analisis ragam dengan selang kepercayaan 95\% menunjukkan bahwa perlakuan jenis rumput laut tidak memberikan pengaruh yang nyata terhadap kadar lemak kue keik. Perlakuan konsentrasi penambahan dan interaksi antar perlakuan memberikan pengaruh yang nyata terhadap kadar lemak produk kue keik yang dihasilkan. Dari uji lanjut Beda Nyata Jujur terhadap perlakuan konsentrasi penambahan bubuk rumput laut diketahui bahwa penambahan 0 dan $5 \%$ tidak memberikan pengaruh yang nyata pada kadar lemak kue keik. Tetapi konsentrasi penambahan bubuk rumput laut sebanyak $1,2,3$, dan $4 \%$ memberikan pengaruh yang nyata kepada kadar lemak kue keik.

Perbedaan nilai kadar lemak ini diduga karena perbedaan kandungan bahan baku awal yang digunakan seperti bubuk rumput laut yang digunakan dan konsentrasi penambahannya. Kandungan lemak bubuk rumput laut lebih besar dibandingkan dengan kadar lemak tepung terigu. Kadar lemak tepung terigu hanya 1,3\% (Direktorat Gizi, 1995), sedangkan kadar lemak bubuk rumput laut Gracilaria spp. sebesar $9,5 \%$ (Badan Penelitian dan Pengembangan Pertanian, 1985), sehingga apabila dilakukan penambahan bubuk rumput laut ke dalam formulasi pembuatan kue keik dapat meningkatkan kadar lemak kue keik yang dihasilkan.

\section{Kadar Karbohidrat}

Kadar karbohidrat produk kue keik yang dihasilkan adalah berkisar antara $33,5-52,3 \%$. Nilai kadar karbohidrat tertinggi diperoleh dari perlakuan penambahan bubuk rumput laut jenis Gracilaria spp. sebanyak $5 \%$, sedangkan perlakuan tanpa penambahan bubuk rumput laut (kontrol) memiliki nilai kadar karbohidrat yang paling rendah

Hasil analisis ragam dengan selang kepercayaan 95\% menunjukkan bahwa perlakuan jenis rumput laut tidak memberikan pengaruh yang nyata terhadap kadar karbohidrat kue keik, sedangkan perlakuan konsentrasi penambahan bubuk rumput laut serta interaksi antar perlakuan memberikan pengaruh yang nyata terhadap kadar karbohidrat produk. Kadar karbohidrat produk kue keik yang dihasilkan bervariasi. Bila dibandingkan dengan produk kontrol maka terjadi kenaikan kadar karbohidrat kue keik yang diberi tambahan bubuk rumput laut. Hal ini diduga karena rumput laut merupakan salah satu sumber karbohidrat yang berupa polisakarida baik dalam bentuk agar, karaginan maupun alginat. Menurut Ishibashi et al., dalam Chapman \& Chapman, 1980 komponen utama dari rumput laut adalah karbohidrat (gula maupun gum alami), sedikit protein, lemak dan abu yang sebagian besar berupa sodium dan potassium serta $80-90 \%$ air

Dari hasil uji lanjut Beda Nyata Jujur terhadap perlakuan konsentrasi penambahan bubuk rumput laut diketahui bahwa penambahan 0,1 dan $2 \%$ tidak memberikan pengaruh yang nyata terhadap kadar 
karbohidrat kue keik, tetapi penambahan 3, 4 dan 5\% bubuk rumput laut memberikan pengaruh yang nyata terhadap kadar karbohidrat produk kue keik. Hal ini berkaitan dengan jumlah penambahan bubuk rumput laut yang diberikan yang semakin meningkat sehingga kadar karbohidrat produk yang dihasilkan juga akan semakin meningkat.

\section{KESIMPULAN DAN SARAN}

1. Kue keik yang dihasilkan masih dapat diterima oleh panelis. Penambahan bubuk rumput laut yang bisa ditambahkan dan paling disukai oleh panelis berdasarkan parameter warna, bau, rasa dan tekstur dibuat dari formula yang menggunakan bubuk Sargassum filipendula $1 \%$ dan bubuk Gracilaria spp. $2 \%$.

2. Kadar air kue keik yang dihasilkan masih cukup tinggi sedangkan kadar abu sudah memenuhi ketentuan sebagai kadar abu untuk makanan. Penambahan $5 \%$ bubuk rumput laut dari kedua jenis rumput laut secara nyata meningkatkan kadar iodium produk namun kurang disukai oleh panelis. Pada penelitian ini terlihat bahwa bubuk rumput laut tidak dapat digunakan sebagai sumber iodium untuk fortifikasi kue keik.

3. Penambahan bubuk Sargassum filipendula dan bubuk Gracilaria spp. ke dalam formula pembuatan kue keik dapat digunakan sebagai salah satu sumber fortifikasi asam lemak omega3.

\section{DAFTAR PUSTAKA}

Anonim. 2002. Mie Beryodium. Kompas Cyber Media 3 Nopember 2004. http://www.kompas.com/kompascetak/0210/20/iptek/kili22. htm.
Anonim. 2003. Menggali Manfaat Rumput Laut. Kompas Cyber Media 3 Nopember 2004. http:// www.kompas.com/kompas-cetak/0307/23/bahari/ 431127. htm.

AOAC. 1984. Official Methods of Analysis. Washington DC.

Apriyantono, A., Fardiaz, D., Puspitasari, N.L., Sedarnawati dan Budiyanto, S. 1989. Petunjuk Laboratorium Analisis Pangan. Pusat Antar Universitas Pangan dan Gizi IPB. Bogor 299 pp.

Badan Penelitian dan Pengembangan Pertanian. 1985 Lokakarya Bioteknologi Rumput Laut 11 - 13 Desember. Departemen Pertanian. Jakarta. p. 9 30.

Chapman, V.J and Chapman, D.J. 1980. Seaweeds and their Uses, Third Edition. Chapman and Hall, New York. 334 pp.

Direktorat Gizi. Departemen Kesehatan. 1995. Daftar Komposisi Bahan Makanan. Direktorat Gizi. Departemen Kesehatan RI. Jakarta.

Indriani, H. dan Sumiarsih, E. 1997. Budidaya, Pengolahan dan Pemasaran Rumput Laut. Penebar Swadaya. Jakarta.

Steel, R.G.D. and Torrie, J.H. 1989. Prinsip dan Prosedur Statistika. (tejemahan) B. Soemantri. PT. Gramedia. Jakarta.

Winarno, F.G. 1990. Teknologi Pengolahan Rumput Laut. Pustaka Sinar Harapan. Jakarta. 1997. Kimia Pangan dan Gizi. PT. Gramedia. Jakarta.

Yunizal, Sri Amini, Irianto, H.E., Ema Hastarini, Siti Hajar, Hanafi dan Abdurrokhim. 2002. Laporan Teknis Penelitian Tahun 2002. Penelitian Biota Laut Penghasil Asam Lemak Omega-3. Pusat Riset Pengolahan Produk dan Sosial Ekonomi Kelautan dan Perikanan, Jakarta : $118 \mathrm{pp}$. 